\title{
Biological activity screening of some hydrazone and chalcone derivatives
}

\section{Bazı hidrazon ve kalkon türevlerinin biyolojik aktivite taraması}

\section{Beguim EVRANOS AKSÖZ ${ }^{1}$ (ID), Fatma KAYNAK ONURDAĞ² (ID), Erkan AKSÖZ ${ }^{3}$ (ID), Selda ÖZGEN ÖZGACAR ${ }^{4}$ (ID)}

\section{ABSTRACT}

Objective: Today, the development of resistance to antibiotics is increasing rapidly. Loss of antibiotics effectiveness due to the development of resistance causes serious hazards. Especially methicillinresistant Staphylococcus aureus and vancomycinresistant Enterococcus faecalis create life-threatening conditions in patients with a weak immune system. For this reason, it is important to develop new drug active substances against these microorganisms. In this article, hydrazones and chalcones were synthesized and some biological activities of these compounds such as antimicrobial and antituberculosis were investigated. This study was conducted to investigate new antimicrobial and antituberculous drug-active substances instead of antibiotics that lost their effectiveness due to the rapidly increasing resistance to existing antibiotics.

Methods: The compounds were obtained by synthesis of chalcones via Claisen Schmidt condensation and then by reacting these chalcones with hydrazides to form hydrazone. Antimicrobial and antituberculosis activities of the compounds were evaluated by microdilution method and microplate alamar blue assays, respectively.

Results: All compounds displayed the same activity against Mycobacterium tuberculosis (MIC: $64 \mu \mathrm{g} / \mathrm{mL}$ ). E4,

\section{ÖZET}

Amaç: Günümüzde antibiyotiklere karșı direnç gelișimi hızla artmaktadır. Direnç gelișmesi nedeniyle antibiyotik etkinliğinin kaybı ciddi tehlikelere neden olmaktadır. Özellikle metisiline dirençli Staphylococcus aureus ve vankomisine dirençli Enterococcus faecalis izolatı, bağıșıklık sistemi zayıf olan hastalarda yașamı tehdit eden durumlar olușturmaktadır. Bu nedenle, bu mikroorganizmalara karșı yeni ilaç etken maddeleri geliștirmek önemlidir. Bu makalede, hidrazonlar ve kalkonlar sentezlenmiș ve bu bileșiklerin antimikrobiyal ve antitüberküloz gibi bazı biyolojik aktivitelerinin araștırılması yapılmıştır. Bu çalıșma, mevcut antibiyotiklere karşı hızla artan direnç nedeniyle etkinliğini kaybeden antibiyotiklerin yerine antimikrobiyal ve antitüberküloz etkili yeni ilaç etken maddelerinin araștırılması için yapılmıștır.

Yöntem: Bileșikler, Claisen Schmidt kondensasyonu yoluyla kalkonların sentezi ve daha sonra bu kalkonların hidrazon olușturmak üzere hidrazidlerle reaksiyona girmesiyle elde edilmiștir. Bileșiklerin antimikrobiyal ve antitüberküloz aktiviteleri, sırasıyla mikrodilüsyon yöntemi ve mikroplak alamar mavisi deneyleri ile değerlendirilmiștir.

Bulgular: Tüm bileșikler Mycobacterium tuberculosis'e karșı aynı etkiyi göstermiștir (Mik: 64 ug/

'Süleyman Demirel University, Faculty of Pharmacy, Department of Pharmaceutical Chemistry, Isparta

${ }^{2}$ Trakya University, Faculty of Pharmacy, Department of Pharmaceutical Microbiology, Edirne

${ }^{3}$ Süleyman Demirel University, Faculty of Pharmacy, Department of Pharmacology, Isparta

${ }^{4}$ Ministry of Health of Turkey, Turkish Medicines and Medical Devices Agency, Ankara

İletişim / Corresponding Author : Begüm EVRANOS AKSÖZ

Süleyman Demirel Üniversitesi Eczacllık fakültesi, Farmasötik Kimya AD, Isparta - Türkiye

E-posta / E-mail : begumevranos@gmail.com

DOI ID : 10.5505/TurkHijyen.2020.02439

Evranos-Aksöz B, Kaynak-Onurdağ F, Aksöz E, Özgen-Özgacar S. Biological activity screening of some hydrazone and chalcone derivatives.

Turk Hij Den Biyol Derg, 2021; 78(2): 159 - 166 
4'-Bromo-4-methyl chalcone, displayed the best activity against Meticilline resistant-Staphylococcus aureus (MIC: $16 \mu \mathrm{g} / \mathrm{mL}$ ). The most effective compounds against Enterococcus faecalis isolate and Enterococcus faecalis were found B26 (N-(1-(4fluorophenyl)-3-p-tolylallylidene) thiophene-2-carbohydrazide) and E8 (4'-fluoro-3-methyl chalcone), respectively (MIC: $32 \mu \mathrm{g} / \mathrm{mL}$ ).

Conclusion: Hydrazones have been found to be more effective than chalcones against S. aureus ATCC 29213. However, chalcones exhibited a remarkable effect against meticilline resistant-Staphylococcus aureus and Enterococcus faecalis. In terms of tuberculosis bacillus, it did not differ whether the compounds had a chalcone or hydrazone structure. Both chalcones and hydrazones exhibited the same activity against candida species. All compounds were observed to be more effective than gentamicin against methicillin-resistant Staphylococcus aureus.

Key Words: Hydrazone, chalcone, antitubercular, antimicrobial, microbial resistance
$\mathrm{mL}$ ). E4, 4'-Bromo-4-metil kalkon, metisiline dirençliStaphylococcus aureus'a karșı en iyi etkinliği göstermiștir (MiK: $16 \mathrm{ug} / \mathrm{mL}$ ). Enterococcus faecalis izolatı ve Enterococcus faecalis'e karșı en etkili bileșikler sırasıyla B26 (N-(1-(4-florofenil)-3-p-tolilaliliden)tiyofen-2karbonhidrazit) ve E8 (4'-floro-3-metil kalkon) olarak bulunmuștur.

Sonuç: Hidrazonların S. aureus ATCC 29213 suşu üzerine kalkonlardan daha etkili olduğu bulunmuștur. Bununla birlikte kalkonlar, metisiline dirençliStaphylococcus aureus ve Enterococcus faecalis üzerine dikkate değer bir etki göstermiștir. Tüberküloz basili açısından, bileșiklerin kalkon veya hidrazon yapısında olması fark göstermemiștir. Hem kalkonlar hem de hidrazonlar kandida türlerine karșı aynı aktiviteyi sergilemiștir. Tüm bileșiklerin metisiline dirençli Staphylococcus aureus üzerine gentamisinden daha etkili olduğu gözlenmiștir.

Anahtar Kelimeler: Hidrazon, kalkon, antituberküloz, antimikrobiyal, mikrobiyal direnç

\section{INTRODUCTION}

Staphylococcus aureus is a microorganism that is important due to its pathogenicity from the beginning of the microbiological era to the present day. This bacterium, which can be found in the skin and mucous flora, can cause fatal diseases such as bacteremia and pneumonia when immunity is weakened. S. aureus, which was previously treatable with penicillins, began to develop resistance to methicillin in the 1960s, resulting in Meticilline resistant-Staphylococcus aureus (MRSA) strains. MRSA has mecA gene which encodes the penicillin- binding protein of MRSA. Thus, resistance to $B$-lactam antibiotics develops (13). Also, MRSA, which started to develop resistance against antibiotics such as linezolid and daptomycin, is a very important health threat $(2,3)$. Resistance was not developed only by $S$. aureus but also by other bacteria that neutralize antibiotics which makes the discovery of new antibiotics is essential.

Balsacone C (figure 1), a dihydrochalcone derivative, draws attention with its activity against MRSA (4). Balsacone C displayed very good activity against 34 MRSA isolates, which are resistant to many antibiotics [Minimum Inhibitory Concentration (MIC): 3-11.6 $\mu \mathrm{g} / \mathrm{mL}$ ] (3). Licochalcone A (Figure 1 ), which is a natural chalcone as balsacone $C$, also shows antibacterial properties (5). Beside its many activities such as antidepressant $(6,7)$ anticonvulsant $(8,9)$, analgesic, antiinflammatory, antiplatelet (10-12) and anticancer (13-16), hydrazones attract researchers with their antibacterial activities. In this study, we synthesized a group of hydrazones and their starting materials, chalcones, and investigated the antimicrobial and antituberculosis activities of these compounds. 


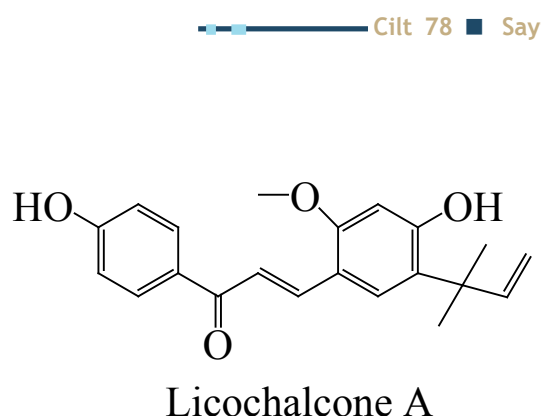

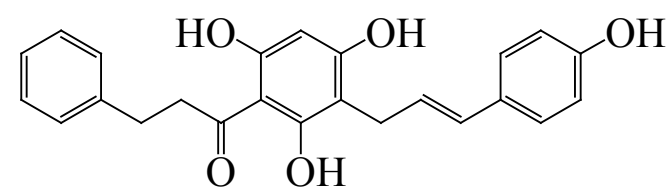

Balsacone $\mathrm{C}$

Figure 1. Some natural antibacterial chalcones

\section{MATERIAL and METHOD}

Details of used chemicals for synthesis (17) and for biological activities (18) and used apparatus to prove the structures of the compounds (17) are given in our previous publications.

\section{Synthesis}

Chalcone derivatives were synthesized by reacting of equimolar amounts of acetophenone and benzaldehyde derivatives in $\mathrm{KOH} /$ methanol. The hydrazone compounds were obtained by reacting the chalcone derivatives with the hydrazide compounds. Reaction and product details have been previously published (18).

\section{Biological activities of compounds}

\section{Antibacterial and antifungal activity}

Antibacterial and antifungal susceptibility testing were applied through CLSI-M100-S16 guidelines (19) and M27-A3 (20) standards, respectively. E. coli ATCC 25922 [1], E. coli ATCC 35218 [2], E. coli isolate (ESBL) [3], P. aeruginosa ATCC 27853 [4], P. aeruginosa isolate (resistant to gentamicin) [5], $S$. aureus ATCC 29213 [6], S. aureus isolate (MRSA) [7], E. faecalis ATCC 29212 [8], E. faecalis isolate (VRE) [9], C. albicans ATCC 10231 [10] and C. krusei ATCC 6258 [11] and their clinical isolates were used in the study. E. coli isolate produces extended spectrum beta lactamase enzyme and used as the ESBL strain. C. krusei ATCC 6258 strain was used because it is resistant to fluconazole naturally. A methicillin resistant S. aureus isolate which is resistant to all beta lactam antibiotics (MRSA), and $E$. faecalis isolate which is resistant to vancomycin (VRE) were also used in the study. The lowest concentrations inhibiting macroscopic growth was determined as MICs. Details of the method is given in the literature (18).

\section{Antitubercular activity}

Mycobacterium tuberculosis H37RV (ATCC 27294) [12] was used as the quality control strain. MABA method was used in order to assess the antituberculosis activity as described by Franzblau et al, 1:1 mixture of 10X Alamar Blue reagent were added to wells. A blue color or a pink color formation indicated no proliferation and proliferation, respectively. The MIC was determined as the lowest drug concentration preventing formation of pink color (21). Details of the method is given in our previous publication (18).

\section{RESULTS}

\section{Chemistry}

Chalcones (E4, E5, E7, E8) (Table 1) were synthesized via Claisen-Schmidt condensation. Then, chalcones were reacted with appropriate hydrazide to give corresponding hydrazones (Table1) as shown in the diagram (Figure 2).

\section{Biological Activity}

Antimicrobial and antitubercular activities of the compounds were examined by using different standards. Antimicrobial activities were examined by microdilution method while antitubercular activities were assessed by microplate alamar blue assay (MABA). Conclusions were given in Table 2. 
Table 1. Formula of compounds

\begin{tabular}{|c|c|c|c|c|}
\hline Compound & $\mathbf{R}^{1}$ & $\mathbf{R}^{2}$ & $\mathbf{R}^{3}$ & $\mathbf{R}^{4}$ \\
\hline B26 & $-F$ & $-\mathrm{H}$ & $-\mathrm{CH}_{3}$ & Thiophene-2-yl (T) \\
\hline B27 & $-F$ & $-\mathrm{CH}_{3}$ & $-\mathrm{H}$ & $\mathrm{T}$ \\
\hline B28 & $-B r$ & $-\mathrm{H}$ & $-\mathrm{CH}_{3}$ & $\mathrm{~T}$ \\
\hline B29 & $-B r$ & $-\mathrm{H}$ & $-\mathrm{CH}_{3}$ & 4-Methyl-1,2,3-thiadiazole-5-yl (MT) \\
\hline B31 & $-\mathrm{Br}$ & $-\mathrm{CH}_{3}$ & $-\mathrm{H}$ & MT \\
\hline E4 & $-\mathrm{Br}$ & $-\mathrm{H}$ & $-\mathrm{CH}_{3}$ & - \\
\hline E5 & $-B r$ & $-\mathrm{CH}_{3}$ & $-\mathrm{H}$ & - \\
\hline E7 & $-F$ & $-\mathrm{H}$ & $-\mathrm{CH}_{3}$ & - \\
\hline E8 & $-F$ & $-\mathrm{CH}_{3}$ & $-\mathrm{H}$ & - \\
\hline
\end{tabular}<smiles>[R]c1ccc(C(C)=O)cc1</smiles>

E4, E5, E7, E8

$\mathrm{R}_{1}=\mathrm{F}, \mathrm{Br} \mathrm{R}^{2}=\mathrm{R}^{3}=\mathrm{CH}_{3}, \mathrm{H}$

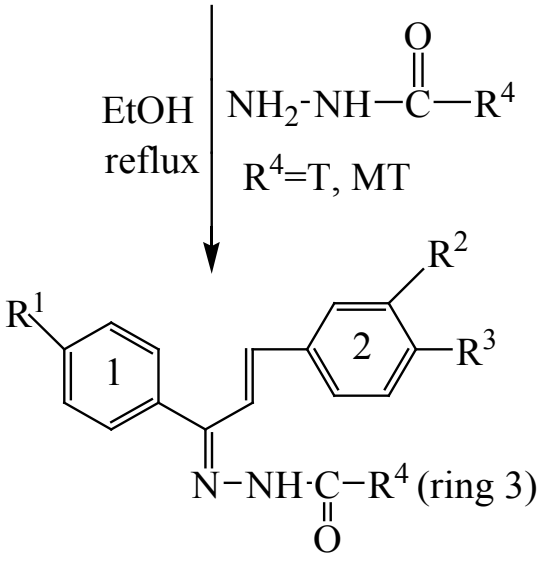

B26, B27, B28, B29, B31

Figure 2. Synthesis of compounds 
Table 2. Antimycobacterial, antifungal and antibacterial activities of compounds

\begin{tabular}{|c|c|c|c|c|c|c|c|c|c|c|c|c|}
\hline Compounds & 1 & 2 & 3 & 4 & 5 & 6 & 7 & 8 & 9 & 10 & 11 & 12 \\
\hline B26 & 64 & 128 & 128 & 64 & 128 & 128 & 64 & 64 & 32 & 128 & 64 & 64 \\
\hline B27 & 128 & 128 & 128 & 128 & 128 & 128 & 64 & 128 & 64 & 128 & 64 & 64 \\
\hline B28 & 64 & 128 & 128 & 128 & 128 & 128 & 64 & 64 & 128 & 128 & 64 & 64 \\
\hline B29 & 64 & 128 & 128 & 128 & 128 & 128 & 64 & 128 & 128 & 128 & 64 & 64 \\
\hline B31 & 128 & 128 & 128 & 128 & 128 & 128 & 64 & 64 & 128 & 128 & 64 & 64 \\
\hline E4 & 128 & 128 & 128 & 64 & 128 & 256 & 16 & 128 & 128 & 128 & 64 & 64 \\
\hline E5 & 128 & 128 & 128 & 64 & 128 & 256 & 64 & 128 & 128 & 128 & 64 & 64 \\
\hline E7 & 128 & 128 & 128 & 64 & 128 & 256 & 64 & 128 & 128 & 128 & 64 & 64 \\
\hline E8 & 128 & 128 & 128 & 64 & 128 & 256 & 32 & 32 & 128 & 128 & 64 & 64 \\
\hline Gentamicin & 0.25 & - & 256 & 1 & 64 & 0.5 & 128 & 8 & 8 & - & - & - \\
\hline Ampicilin & 2 & - & $>1024$ & - & - & 0.5 & - & 0.5 & 0.5 & - & - & - \\
\hline Meropenem & 0.008 & - & 0.015 & 0.25 & 0.015 & 0.03 & - & 4 & 8 & - & - & - \\
\hline Ofloxacin & 0.015 & - & 16 & 1 & 1 & 0.125 & 0.5 & 1 & 4 & - & - & - \\
\hline Fluconazol & - & - & - & - & - & - & - & - & - & 0.0625 & 32 & - \\
\hline Vancomycin & - & - & - & - & - & 0.5 & 1 & 1 & 8 & - & - & - \\
\hline Amphotericin B & - & - & - & - & - & - & - & - & - & $<0.03$ & 0.5 & - \\
\hline $\begin{array}{c}\text { Ampicilin/ } \\
\text { sulbactam (1/1) }\end{array}$ & - & 16 & - & - & - & - & - & - & - & - & - & - \\
\hline $\begin{array}{c}\text { Amoxicilin/ } \\
\text { clavulonic acid } \\
(2 / 1)\end{array}$ & - & 16 & - & - & - & - & - & - & - & - & - & - \\
\hline Ethambuthol & & & & & & & & & & & & 4 \\
\hline Isoniazid & & & & & & & & & & & & 0.125 \\
\hline
\end{tabular}

Names of the bacteria and explanation of numbers in the table and article is given in Materials and Methods.

MIC: $\mu \mathrm{g} / \mathrm{mL}$ 


\section{DISCUSSION}

Compounds B26, B28 and B29 were displayed the best activity against $E$. coli [1] (MIC=64 $\mu \mathrm{g} / \mathrm{mL})$. Against this strain, hydrazone derivatives have been shown to be more effective than chalcones. B27, a derivative of hydrazone, had the same activity as chalcones. For this activity, it is important that ring 2 has methyl in the para position. Placing the methyl group in the meta position instead of para reduced the activity. Chalcones generally outperformed than hydrazones against Pseudomonas aeruginosa ATCC 27853. One of the hydrazones, compound B26, showed the same activity as chalcones. E4, a compound in the structure of chalcone containing bromine at 4th position of ring 1 and methyl at 4th position of ring 2 , showed the best activity against MRSA $(M I C=16 \mu \mathrm{g} / \mathrm{mL})$. The E8 compound, which is a chalcone carrying fluorine atom in the 4th position of ring 1 and carrying methyl in the meta position of ring 2, was the second compound showing the best activity against MRSA. According to $\mathrm{Xu}$ et al., electron-withdrawing $(-\mathrm{Cl},-\mathrm{F}$ and $-\mathrm{Br})$ groups at the 2nd and 4th positions of phenyl ring is more preferable for antibacterial activity than electrondonating (-Me and -OMe) substituents (22).

The E8 compound was found to be the most active compound against $E$. faecalis [8] (MIC $=32 \mu \mathrm{g} / \mathrm{mL})$. It is observed that the activity decreases in $\mathbf{B 2 7}$, which is the hydrazone formed by the reaction of E8 with thiophene hydrazide. Against this microorganism, compounds B26, B28 and B31 showed the same activity $(M I C=64 \mu \mathrm{g} / \mathrm{mL})$. B26 is the most effective compound with $32 \mu \mathrm{g} / \mathrm{mL}$ MIC against VRE, which contains fluorine atom in position 4 of the first ring, methyl in position 4 of the 2 nd ring, and thiophene as the 3rd ring. Unlike B26, compound B27 maintains the methyl in the meta position of ring 2 instead of para. B27 was found to be the second most effective compound $(\mathrm{MIC}=64 \mu \mathrm{g} / \mathrm{mL}$ ) against VRE. Therefore, including p-methyl on the 2nd ring is important for the activity against VRE. All compounds except B26 and B27 displayed the same activity against VRE $(M I C=128 \mu \mathrm{g} / \mathrm{mL})$. Unlike B26, B28 compound has $\mathrm{p}$-bromine instead of $\mathrm{p}$-fluorine of the 1 st ring. The replacement of the fluorine atom with a bromine atom caused a serious decrease in the activity. For the activity against VRE, presence of p-fluorine at the 1st ring and the presence of the methyl group in the 4th position of the 2 nd ring is necessary. When the methyl group attached to the second ring is taken into the meta position instead of para, the activity decreases. Both chalcone and hydrazone derivatives displayed the same activity against $E$. coli [2], ESBL, P. aeruginosa [5], C. albicans, C. krusei and $M$. tuberculosis strains. Hydrazones were found to be more effective than chalcones against $S$. aureus [6].

In summary, some chalcones and their hydrazones were designed, synthesized and their antitubercular and antimicrobial activities were examined. Compound E4 with its activity against MRSA, compound E8 against $E$. faecalis and compound B26 against VRE came into prominence. It is hoped that our study can contribute to the development of new antibiotics in an environment where bacterial resistance development is so frequent. Further studies are necessary to find the antibiotics.

\section{ETHICS COMITTEE APPROVAL}

* This study does not require Ethics Committee Approval. 


\section{CONFLICT OF INTEREST}

The authors declare no conflict of interest.

\section{REFERENCES}

1. Lowy FD. Antimicrobial resistance: the example of Staphylococcus aureus. J Clin Invest, 2003; 111: 1265-73.

2. Monaco M, Araujo FP, Cruciani M, Coccia EM, Pantosti A. Worldwide epidemiology and antibiotic resistance of Staphylococcus aureus. Curr Top Microbiol Immunol, 2017; 409: 21-56.

3. Côté $H$, Pichette A, Simard F, Ouellette ME, Ripoll $\mathrm{L}$, Mihoub $\mathrm{M}$, et al. Balsacone $\mathrm{C}$, a new antibiotic targeting bacterial cell membranes, inhibits clinical isolates of methicillin-resistant Staphylococcus aureus (MRSA) without inducing resistance. Front Microbiol, 2019; 10: 2341.

4. Riviere C. Dihydrochalcones: Occurence in the plant kingdom, chemistry and biological activities. In: Atta-ur Rahman (Ed.). Studies in Natural Products Chemistry. John Fedor Publisher, Elsevier, Amsterdam, Netherlands, 2016; 253-373.

5. Osório TM, Monache FD, Chiaradia LD, Mascarello A, Stumpf TS, Zanetti CR, et al. Antibacterial activity of chalcones, hydrazones and oxadiazoles against methicillin-resistant Staphylococcus aureus. Bioorg Med Chem Lett, 2012; 22: 225-30.

6. De Oliveira KN, Costa P, Santin JR, Mazzambani L, Bürger C, Mora C, et al. Synthesis and antidepressant-like activity evaluation of sulphonamides and sulphonyl-hydrazones. , 2011; 19(14): 4295-306.

7. Can ÖD, Altıntop MD, Özkay ÜD, Üçel UI, Doğruer B, Kaplancıklı ZA. Synthesis of thiadiazole derivatives bearing hydrazone moieties and evaluation of their pharmacological effects on anxiety, depression, and nociception parameters in mice. Arch Pharm Res, 2012; 35(4): 659-69.
8. Sridhar SK, Pandeya SN, Stables JP, Ramesh A. Anticonvulsant activity of hydrazones, schiff and mannich bases of isatin derivatives. Eur J Pharm Sci, 2002; 16: 129-32.

9. Angelova V, Karabeliov V, Andreeva-Gateva PA, Tchekalarova J. Recent developments of hydrazide/hydrazine derivatives and their analogs as anticonvulsant agents in animal models. Drug Dev Res, 2016; 77: 379-92.

10. Rollas S, Küçükgüzel SG. Biological activities of hydrazone derivatives. Molecules, 2007; 12: 191039.

11. Asif M, Husain A. Analgesic, anti-inflammatory, and antiplatelet profile of hydrazones containing synthetic molecules. Journal of Applied Chemistry, 2013; 2013: Article ID 247203, 7 pages.

12. Verma G, Marella A, Shaquiquzzaman M, Akhtar M, Ali MR, Alam MM. A review exploring biological activities of hydrazones. J Pharm Bioallied Sci, 2014; 6(2): 69-80.

13. Sundaree $S$, Vaddula BR, Tantak MP, Khandagale SB, Shi C, Shah K, et al. Synthesis and anticancer activity study of indolyl hydrazide-hydrazones. Med Chem Res, 2016; 25: 941-50.

14. Shah P, Abadi LF, Gaikwad S, Chaudhari D, Kushwah V, Jain S, et al. Synthesis and biological evaluation of 8-hydroxyquinoline-hydrazones for Anti-HIV-1 and anticancer potential. Chemistry Select, 2018; 3: $10727-31$.

15. Şenkardeș S, Han Mi, Kulabaș N, Abbak M, Çevik Ö, Küçükgüzel $i$, et al. Synthesis, molecular docking and evaluation of novel sulfonyl hydrazones as anticancer agents and COX-2 inhibitors. Mol Divers 2019. 
16. Alotabi SH. Synthesis, characterization, anticancer activity, and molecular docking of some new sugar hydrazone and arylidene derivatives. Synthesis, characterization, anticancer activity, and molecular docking of some new sugar hydrazone and arylidene derivatives. Arab J Chem, 2020; 13: 4771-84.

17. Evranos Aksoz B, Baysal I, Yabanoglu-Ciftci S, Djikic T, Yelekci K, Ucar G, et al. Synthesis and screening of human Monoamine oxidase-A inhibitor effect of new 2-pyrazoline and hydrazone derivatives. Arch Pharm. 2015; 348: 743-56.

18. Evranos Aksöz B, Onurdağ FK, Özgacar SÖ. Antibacterial, antifungal and antimycobacterial activities of some pyrazoline, hydrazone and chalcone derivatives. Z Naturforsch C, 2015; 70(78): 183-9.

19. Clinical and Laboratory Standards Institute (CLSI) (formerly NCCLS). 2006a. Performance standards for antimicrobial susceptibility testing 6th informational supplement. CLSI M100-S16, Clinical and Laboratory Standards Institute, 940 West Valley Road, Wayne, Pennsylvania, USA.
20. Clinical and Laboratory Standards Institute (CLSI) (formerly NCCLS). 2006b. Reference method for broth dilution antifungal susceptibility testing of yeast approved standard, M27-A, clinical and laboratory standards institute, 940 West Valley Road, Wayne, Pennsylvania, USA

21. Franzblau SG, Witzig RS, McLaughlin JC, Torres P, Madico G, Hernandez A, et al. Rapid, lowtechnology MIC determination with clinical Mycobacterium tuberculosis isolates by using the microplate alamar blue assay. J Clin Microbiol, 1998; 36: 362-6.

22. Xu M, Wu P, Shen F, Ji J, Rakesh KP. Chalcone derivatives and their antibacterial activities: current development. Bioorg Chem, 2019; 91: 10333. 